\title{
IMPLEMENTASI PENDIDIKAN KARAKTER KEMANDIRIAN DI MUHAMMADIYAH BOARDING SCHOOL
}

\author{
Wuri Wuryandani, Fathurrohman, dan Unik Ambarwati \\ Fakultas Ilmu Pendidikan Universitas Negeri Yogyakarta \\ email: Email: wuri_wuryandani@uny.ac.id
}

\begin{abstract}
Abstrak: Penelitian bertujuan untuk menjelaskan implementasi pendidikan karakter kemandirian di Muhammadiyah Boarding School (MBS), menentukan kebijakan dan strategi dalam menginternalisasikan nilai-nilai karakter kemandirian. Penelitian menggunakan pendekatan kualitatif. Pengumpulan data yang dilakukan lewat teknik observasi, wawancara, dan dokumentasi, sedang analisis lewat teknik induktif melalui langkah reduksi data, unitisasi dan kategorisasi, display data, dan penarikan kesimpulan.

Temuan penelitian menunjukkan hasil sebagai berikut. Pertama, kebijakan untuk membangun kemandirian dalam diri santri dilakukan lewat kemandirian belajar, mengatur diri pribadi, memanajemen waktu. Kedua, kemandirian dalam proses pembelajaran guru menggunakan strategi penugasan yang menuntut santri untuk secara mandiri memanfaatkan sumber belajar, membuat kontrak belajar, dan mengintegrasikan pendidikan karakter kemandirian dalam proses belajar mengajar di kelas. Ketiga, terkait dengan kendala yang dialami sekolah dalam implementasi pendidikan karakter kemandirian adalah kurang konsistensinya orang tua dan adanya beberapa guru yang belum mengintegrasikan pendidikan karakter kemandirian dalam proses pembelajaran.
\end{abstract}

\section{Kata Kunci: pendidikan karakter, kemandirian, Boarding School}

\section{THE IMPLEMENTATION OF SELF-RELIANCE CHARACTER EDUCATION AT MUHAMMADIYAH BOARDING SCHOOL}

\begin{abstract}
The goal of this research is to delineate the implementation of self-reliance character education at Muhammadiyah Boarding School (MBS) so as to determine relevant policies and strategies in order to internalize the character values of self-reliance. Using descriptive qualitative approach, the techniques for collecting data included observation, interview, and documentation. Data were analyzed using inductive method, involving data reduction, categorization, display and conclusion. The results of this research are: firstly, in order to implement self-reliancecharacter education, students' self-reliance can be built through independent learning, self and time management. Secondly, teachers may use various strategies, for instance, task assignment which requires students to use learning resources, formulating learning rules, and integrating character education in the learning process. Thirdly, parents'and teachers' inconsistencyare found to bethe obstacles in implementing such character education.
\end{abstract}

Keywords: character education, self-reliance, boarding school

\section{PENDAHULUAN}

Pendidikan merupakan usaha untuk membentuk siswa menjadi warga negara yang baik (good citizen) sehingga kelak mampu menjalankan perannya dalam wadah Negara Kesatuan Republik Indonesia. Dalam rangka mewujudkan hal tersebut, dalam proses pendidikan sudah seharusnya siswa dibekali dengan nilai-nilai karakter yang baik. Melalui bekal nilai karakter yang baik tersebut diharapkan mereka lebih mudah untuk berinteraksi dan beradaptasi dengan lingkungan sekitarnya.
Salah satu nilai karakter yang perlu dikembangkan adalah kemandirian. Di era sekarang ini nilai kemandirian merupakan salah satu nilai karakter yang perlu mendapatkan perhatian. Hal ini disebabkan bahwa di masa sekarang banyak keluarga yang memperlakukan anak dengan melayani sepenuhnya kebutuhan anak dari bangun tidur hingga tidur kembali. Apalagi anak-anak yang kehidupan sehari-harinya selalu didampingi oleh asisten rumah tangga yang disebabkan orang tuanya sibuk bekerja di luar rumah. 
Nilai karakter kemandirian dalam pengembangan membutuhkan usaha agar siswa dapat memiliki pengetahuan tentang karakter kemandirian, sikap kemandirian, dan menampilkan perilaku kemandirian. Hal ini sesuai dengan pendapat Lickona (1994), yaitu bahwa seseorang dikatakan memiliki karaker yang baik jika memenuhi komponen-komponen moral knowing, moral feeling, dan moral action. Berdasarkan penjelasan tersebut, jelaslah bahwa pendidikan karakter yang dilakukan tidak boleh hanya menyentuh salah satu apek secara parsial, misalnya pengetahuan moral saja, tetapi harus diupayakan agar sampai pada aspek perasaan dan perilaku moral.

Suparno (2012:8) menjelaskan bahwa pendidikan kita masih terlalu menekankan segi kognitif, yang masih terbatas pada mencari angka, bukan kemampuan analisis kritis siswa terhadap peristiwa yang dihadapi dalam kehidupan seharihari. Jika hal tersebut berlangsung secara terus menerus, bisa jadi inilah penyebab pendidikan karakter kurang bisa mencapai tujuannya secara optimal. Oleh karena itu jika sekolah hanya menitikberatkan pembelajaran pada aspek kognitif saja, akan mengakibatkan nilai-nilai karakter yang seharusnya diinternalisasikan ke dalam diri siswa kurang mendapatkan perhatian dalam proses pembelajaran di sekolah.

Penyebab gagalnya pendidikan karakter di sekolah juga disampaikan oleh Hakam (Budimansyah, 2012:85) bahwa kegagalan pendidikan nilai (agama dan moral) dikarenakan sekolah masih terbatas pada penyampaian moral knowing dan moral training,tetapi tidak menyentuh moral bein, yaitu membiasakan anak untuk terus-menerus melakukan perbuatan moral. Oleh karena itu, penting kiranya bahwa sekolah harus memiliki kebijakan-kebijakan yang tepat untuk mengimplementasikan pendidikan karakter kemandirian. Untuk dapat berperilaku mandiri secara terus-menerus, salah satu hal yang perlu dikembangkan adalah adanya lingkungan sekolah yang kondusif.

Lingkungan sekolah yang kondusif untuk pembudayaan nilai-nilai karakter adalah jika di dalam sekolah tersebut diciptakan suasana yang memberikan kesempatan kepada seluruh warga sekolah untuk membiasakan diri berperilaku sesuai dengan tuntunan yang baik. Suasana sekolah yang kondusif meliputi seuruh lingkungan sekolah, baik dalam pembelajaran maupun di luar pembelajaran. Dalam suasana pembelajaran hendaknya guru menciptakan aktivitas kelas yang dapat dijadikan sebagai wahana untuk pengembangan karakter siswa. Wynne (1991:139) mengemukakan bahwa aktivitas di dalam kelas lebih banyak untuk pengembangan nilai-nilai karakter. Demikian pula untuk lingkungan sekolah di luar pembelajaran harus memberikan kesempatan kepada siswa untuk berperilaku sesuai dengan yang diharuskan.

Penelitian ini memfokuskan pada implementasi pendidikan karakter kemandirian di $\mathrm{Mu}-$ hammadiyah Boarding School (MBS). Penelitian dilatar belakangi bahwa di sekolah berasrama seperti MBS banyak kegiatan sekolah, baik yang masuk ke dalam aktivitas pembelajaran maupun di luar aktivitas pembelajaran yang syarat dengan muatan nilai-nilai karakter kemandirian. Seperti diketahui bahwa MBS merupakan sekolah yang menuntut anak untuk tidak selalu tergantung kepada orang tua atau asisten rumah tangga di rumah. Melalui kegiatan di sekolah yang berasrama ini diharapkan nilai-nilai karakter yang baik akan mampu terinternalisasi dalam diri siswa secara optimal.

Lickona (1994:51) menjelaskan bahwa komponen karakter yang baik meliputi tiga hal, yaitu pengetahuan moral, perasaan moral, dan perilaku moral. Karakter yang baik adalah terdiri dari mengetahui yang baik, menginginkan yang baik, dan melakukan kebiasaan baik dari pikiran, kebiasaan hati, dan kebiasaan tindakan. Seseorang dikatakan memiliki karakter yang baik jika ia tidak hanya tahu tentang karakter yang baik, tetapi juga diwujudkan dalam perilaku sehari-harinya.

Dalam upaya membangun karakter peserta didik harus didukung dengan lingkungan yang baik. Hal ini senada dengan pendapat Lickona (1994:63) bahwa karakter tidak berfungsi dalam ruang hampa, ini berfungsi dalam lingkungan sosial. Lingkungan biasanya menekankan pada nilai moral yang diinginkan.

Berdasarkan penjelasan di atas, tidak dapat dipungkiri bahwa siswa di sekolah tidak hanya cukup dikembangkan aspek akademik saja, tetapi juga aspek moralnya. Perubahan perilaku siswa merupakan salah satu yang perlu mendapat perhatian guru di sekolah. Watson (2010:175) menjelaskan bahwa siswa dipandang secara alamiah sebagai papan tulis yang kosong yang akan dibentuk melalui penguatan untuk menjadi pelajar dan warga negara yang produktif. Oleh karena itu, tugas pendidikan bukan hanya cukup mengembang- 
kan aspek kognitif, tetapi juga aspek afektif.

Adapun bentuk pendidikan karakter yang diimplementasikan hendaknya merupakan pendidikan karakter yang komprehensif. Pendidikan karakter yang komprehensif dijelaskan dalam 11 prinsip sebagai berikut: (1) mempromosikan nilai-nilai etika inti sebagai dasar karakter yang baik; (2) mendefinisikan karakter secara komprehensif dengan memasukkan berpikir, merasa, dan perilaku; (3) menggunakan pendekatan yang komprehensif, proaktif, dan efektif untuk pengembangan karakter; (4) menciptakan kepedulian komunitas sekolah; (5) memberikan kesempatan siswa untuk tindakan moral; (6) memasukkan kurikulum akademik yang bermakna dan menantang yangmenghormati semua peserta didik, mengembangkan karakter mereka, dan membantu mereka untuksukses; (7) berusaha untuk mendorong motivasi diri siswa; (8) melibatkan staf sekolah dalam pembelajaran dan komunitas moral yang bertanggung jawab dalam pendidikan karakter dan upaya untuk mematuhi nilai-nilai inti yang sama dalam membimbing pendidikan siswa; (9) memupuk kepemimpinan moral bersama dan mendukung inisiatif pendidikan karakter dalam jangka panjang; (10) melibatkan keluarga dan anggota masyarakat sebagai mitra dalam upaya pembangunan karakter; (11) mengevaluasi karakter sekolah, fungsi staf sekolah sebagai pendidik karakter, dan sejauh mana siswa memanifestasikan karakter yang baik (Glanzer \& Milson, 2006:534).

Nilai karakter kemandirian merupakan salah satu hal penting yang harus dikembangkan sekolah guna membentuk generasi muda yang mandiri. Peserta dididk yang mandiri diharapkan mampu 1) lebih percaya diri dalam bertindak, 2) mempertimbangkan pendapat dan nasihat dari orang lain, 3) memiliki kemampuan mengambil keputusan, dan 4) tidak mudah terpengaruh oleh orang lain (Fajaria, 2013:12).

Ahmadi menjelaskan bahwa kemandirian belajar adalah sebagai belajar mandiri, tidak menggantungkan diri pada orang lain (Aini \& Taman, 2012:54). Berdasarkan pendapat tersebut diharapkan siswa yang memiliki bekal kemandirian yang baik akan mampu berlatih untuk mampu mengurangi ketergantungannya kepada orang lain.

\section{METODE}

Penelitian ini merupakan penelitian deskriptif dengan pendekatan kualitatif yang bermaksud menggambarkan, mengungkap, dan menjelaskan implementasi pendidikan karakter kemandirian di Muhammadiyah Boarding School (MBS).

Teknik pengumpulan data yang digunakan adalah observasi, wawancara, dan dokumentasi. Teknik wawancara digunakan untuk memperoleh informasi tentang kebijakan sekolah untuk menginternalisasikan nilai-nilai karakter kemandirian, strategi yang guru dalam menciptakan pembelajaran yang bermuatan nilai-nilai karakter, dan pengalaman belajar siswa berkaitan dengan nilai-nilai karakter. Observasi digunakan untuk memperoleh data atau informasi tentang strategi yang dilakukan oleh kepala sekolah, guru untuk menginternalisasikan nilai-nilai karakter yang diaplikasikan baik di dalam kelas maupun di luar kelas. Dokumentasi digunakan untuk memperoleh data mengenai program sekolah untuk pelaksanaan pendidikan karakter, rencana pelaksanaan pembelajaran yang dibuat guru sebagai pedoman tertulis dalam proses belajar mengajar di kelas, dokumentasi proses pembelajaran baik di dalam maupun di luar kelas. .

Pemeriksaan keabsahan data menggunakan teknik triangulasi baik teknik maupun metode. Jika pada proses triangulasi data tersebut valid, dijadikan sebagai data untuk menjawab fokus masalah penelitian. Di samping itu, terdapat beberapa data yang menggunakan teknik pemeriksaan keabsahan data dengan cross chek. Analisis data kualitatif menggunakan teknik analisis induktif, yaitu analisis yang bertolak dari data dan bermuara pada simpulan-simpulan umum. Langkah-langkah analisis data tersebut meliputi: reduksi data, unitisasi dan kategorisasi, display data, dan penarikan kesimpulan.

\section{HASIL DAN PEMBAHASAN Hasil}

Berdasarkan penelitian yang dilakukan terkait dengan implementasi pendidikan karakter kemandirian di Muhammadiyah Boarding School (MBS) Yogyakarta, dapat dipaparkan data-data hasil penelitian sebagai berikut. 


\section{Kebijakan Implementasi Pendidikan Karakter Kemandirian Pembiasaan}

Muhammadiyah Boarding School (MBS) merupakan sekolah yang dalam kegiatan sehariharinya banyak diwarnai dengan pembiasaan untuk menanamkan nilai karakter kemandirian pada siswanya.Kegiatan ini dilakukan sepanjang hari mulai dari kegiatan asrama, pembelajaran, dan kembali ke asrama. Kegiatan di asrama diawali dengan pembiasaan untuk membangun kemandirian siswa dalam hal mengurus keperluan diri.

Data terkait dengan pembiasaan untuk pengembangan kemandirian siswa diperoleh melalui wawancara, observasi, dan dokumentasi. Berdasarkan hasil wawancara dengan pengelola asrama diperoleh data bahwa siswa dibiasakan untuk berlatih mengelola kebutuhan diri secara mandiri. Kegiatan ini ditunjukkan dengan pembiasaan untun mencuci baju sendiri. Data hasil wawancara ini didukung dengan data hasil observasi di asrama bahwa siswa secara mandiri mengerjakan tugas untuk mencuci baju sendiri. Dalam hal ini siswa secara mandiri juga saling berbagai waktu dengan teman untuk kegiatan mencuci. Kedua data tersebut didukung pula dengan hasil analisis dokumen. Dalam aturan asrama ada butir aturan yang menuntut siswa untuk mengurus sendiri keperluannya terkait dengan pakaian mereka sehari-hari.

Kegiatan lain yang terkait dengan pembiasaan mengurus kebutuhan diri sendiri terkait dengan makan. Berdasarkan hasil wawancara dengan pengelola asrama, diperoleh data bahwa siswa secara mandiri dibiasakan untuk mengatur kebutuhan makan secara bergiliran. Pihak asrama hanya mempersiapkan makanan, sementara untuk membagi, beres-beres alat makan menjadi tugas siswa sendiri. Mereka secara mandiri dan bergiliran mengatur tata cara makan hingga memersihkan peralatan makan. Data tersebut diperkuat dengan data hasil observasi dimana siswa secara bergiliran mengatur tata cara pembagian makanan, sampai pada bersih-bersih alat makan dan membereskannya. Pembiasaan untuk mengelola tata cara makan dan membereskan peralatannya ini didukung dengan data dokumentasi di mana dalam setiap kamar ada aturan yang memungkinkan siswa secara mandiri bertanggung jawab terhadap tugas pengelolaan makan sisang, hingga membereskan peralatan makan.
Pengembangan kemandirian yang lainnya terkait dengan pembiasaan siswa untuk menentukan pilihan. Ketika peneliti melakukan penelitian terlihat di beberapa ruang kelas di luar jam sekolah siswa berkumpul untuk bermusyawarah menentukan lokasi field trip. Berbagai alasan dan pertimbangan mereka share dalam diskusi tersebut. Tanpa harus menunggu kehadiran guru pun musyawarah berlangsung secara serius. Hal ini diperkuat dengan dengan data hasil wawancara dengan guru bahwa siswa banyak diberikan kebebasan untuk secara mandiri menentukan pilihannya.

Data penelitian lainnya yang terkait dengan kebijakan sekolah dalam implementasi pendidikan karakter kemandirian untuk mengatur waktu belajar. Berdasarkan data hasil wawancara dengan pengelola asrama diperoleh penjelasan bahwa siswa diberikan kebebasan untuk mengatur jadwal belajarnya sendiri. Memang untuk jam belajar secara umum ditetapkan oleh sekolah, tetapi untuk materi pelajaran atau jenis kegiatan belajar yang dilakukan santri di jam belajar diserahkan sepenuhnya kepada santri yang bersangkutan di bawah pengawasan ketua kamar. Dengan demikian, masing-masing santri secara mandiri menentukan apa yang akan dipelajari dan bagaimana cera mereka belajar di jam berlajar tersebut.

Penjelasan pihak sekolah terkait dengan pengembangan kemandirian belajar ini diperkuat dengan penjelasan siswa yang menyatakan bahwa memang ditetapkan watu belajarnya oleh pondok, tetapi tentang materi pembelajaran dan cara belajar sepenuhnya diserahkan kepada masing-masing santri. Mayoritas dari santri tersebut memilih untuk belajar materi yang akan mereka pelajari besok hari dan mengerjakan PR yang diberikan guru. Ketika waktu belajar tiba, maka semua santri melakukannya di ruang kelas (ruang belajar), tidak diperkenankan di kamar masing-masing.

Data hasil wawancara tersebut diperkuat dengan data hasil observasi yang menunjukkan bahwa siswa secara mandiri mengelola waktu belajarnya tanpa harus secara terus menerus diawasi oleh pengelola asrama. Jika tiba waktu jam belajar, secara teratur siswa menuju ruang belajar dan mulai aktivitas belajar dengan sendirinya. Pengelola asrama tidak harus memonitorig secara khusus satu per satu.

Berdasarkan hasil wawancara dan dan observasi tersebut dapat disimpulkan bahwa pembiasaan untuk melatih kemandirian siswa dalam 
mengatur jam belajar telah dilakukan di MBS. Pembiasaan ini secara terus menerus dilaksanakan di MBS.

\section{Terintegrasi dalam Pembelajaran}

Strategi guru dalam mengimplementasikan pendidikan karakter kemandirian melalui kegiatan: 1) penugasan yang menuntut siswa memanfaatkan berbagai sumber belajar yaitu perpustakaan dan internet, 2) mengreasi kelas sesuai kreativitas masing-masing santri, dan 3) pembuatan kontrak belajar di masing-masing kelas.

Terkait dengan kegiatan penugasan, berdasarkan hasil wawancara dengan guru diperoleh data bahwa dalam upaya mengembangkan kemandirian belajar santri melalui proses pembelajaran, guru melakukan aktivitas pemberian penugasan kepada siswa yang menstimulasi siswa untuk mandiri dalam memilih berbagai sumber belajar dalam penyelesaian tugas tersebut. Data penelitian menunjukkan bahwa dalam upaya penyelesaian tugas yang diberikan guru, siswa secara mandiri mampu memanfaatkan sumber belajar yang ada, yaitu di antaranya perpustakaan.

Data wawancara dengan guru tersebut diperkuat dengan hasil wawancara dengan siswa yang memaparkan bahwa dalam upaya menyelesaikan tugas dari guru siswa banyak memanfaatkan sumber belajar yang ada, yaitu perpustakaan dan fasilitas internet yang ada di lingkungan pesantren. Pemanfaatan sumber belajar ini sepenuhnya diserahkan kepada siswa untuk memilih sesuai dengan kebutuhannya.

Strategi selanjutnya adalah melalui kegiatan mengreasi kelas mmasing-masing kelas sesuai kreativitas siswa sendiri. Dalam hal ini siswa diberi kebebasan oleh guru untuk memanfaatkan alat-alat yang ada dan beberapa barang bekas untuk mengkreasi kelasnya. Secara mandiri siswa mencari bahan untuk mengkreasi kelasnya. Seperti yang dituturkan oleh salah satu guru bahwa beberapa dari siswa mampu memanfaatkan bekas karung semen untuk kemudian dikreasikan menjadi beberapa karya untuk menghias kelasnya.

Data dari wawancara dengan guru tersebut diperkuat dengan data wawancara dengan santri. Beberapa siswa menuturkan bahwa dalam upaya mengreasi kelasnya mereka melakukan perundingan secara bersama-sama untuk menentukan bagaimana kelas mereka akan dihias dengan berbagai karya siswa. Kegiatan diskusi yang dilakukan santri tidak terbatas hanya untuk materi mengkreasi siswa, tetapi juga ketika santri hendak mengadakan kegiatan kelas bersama-sama, misalnya memperingati hari kemerdekaan Indonesia.

Selain dua kegiatan tersebut, untuk mengembangkan kemandirian siswa melalui pembelajaran, guru mengadakan kontrak belajar dengan siswa. Kontrak belajar tidak semata-mata dari guru, tetapi siswa secara mandiri menentukan aturan main dalam kelas untuk proses belajar mengajar. Data wawancara dengan guru ini diperkuat dengan data dokumen yang ditemukan peneliti di beberapa kelas.Dalam beberapa kelas ditemukan adanya dokumen kontrak belajar yang ditempel di dinding.

Kebijakan-kebijakan yang diimplementasikan di MBS bukanlah kebijakan yang muncul secara insidental.Kebiajakan-kebijakan tersebut telah dituangkan dalam aturan tertulis berupa aturan asrama, aturan sekolah, dan aturan kelas. Semua aturan tersebut berfungsi untuk mempertegas kebijakan-kebiajan yang dimiliki sekolah.

\section{Kendala dalam Implementasi Pendidikan Karakter Kemandirian}

Pengembangan pendidikan karakter kemandirian tidaklah tanpa kendala. Beberapa kendala yang dialami oleh pihak sekolah di antaranya meliputi: 1) kurang konsistennya orang tua dalam mengikuti aturan sekolah untuk mengembangkan karakter kemandirian, 2) sekolah belum mampu untuk mengintegrasikan pendidikan karakter kemandirian secara komprehensif dalam proses pembelajaran di kelas.

Kendala yang pertama, yaitu kurang konsistennya orang tua dalam mengikuti aturan sekolah untuk mengembangkan karakter kemandirian diantaranya beberapa oraang tua tidak "tega" melepas anaknya untuk menjalani kehidupan di pesantren. Hal ini terutama berkaitan dengan pemberian layanan atau fasilitas yang masih memungkinkan santri untuk bergantung kepada orang tua. Hal ini banyak terjadi pada santri-santri baru.

Kendala yang kedua, yaitu terkait dengan pengintegrasian pendidikan karakter kemandirian ke dalam proses pembelajaran. Beberapa guru mata pelajaran menuturkan bahwa merasa kesulitan untuk mengkaitkan materi mata pelajaran dengan pengembangan kemandirian santri. Dengan demikian, kadang-kadang masih terjadi kesulitan yang dialami guru dalam mengimplementasikan pendidikan karakter kemandirian melalui proses pembelajaran. 


\section{Pembahasan}

\section{Kebijakan Implementasi Pendidikan Karakter Kemandirian}

Kebijakan yang ditempuh dalam implementasi pendidikan karakter kemandirian di MBS dilakukan dengan melalui kegiatan pembiasaan, terintegrasi dalam pembelajaran, dan dituangkan dalam aturan tertulis. Melalui kegiatan tersebut diharapkan akan mampu tercipta iklim sekolah yang kondusif untuk mendukung keberhasilan pelaksanaan implementasi pendidikan karakter kemandirian.

Iklim sekolah yang kondusif sangat diperlukan dalam pendidikan karakter. Hal ini karena melalui iklim kelas yang kondusif sangat baik untuk mendukung agar siswa dapat berperilaku mandiri dalam kegiatan sehari-hari di sekolah (baik dalam lingkungan asrama maupun kelas). Penciptaan lingkungan kelas yang kondusif untuk mendukung terinternalisasinya karakter kedisiplinan kepada siswa dipertegas pula oleh pendapat Berry (1994:5).

Dupper (2010:18) menjelaskan bahwa iklim lingkungan sekolah yang yang positif perlu diciptakan dengan memperhatikan kriteria sebagai berikut: 1) keadaan fisik sekolah yang menarik, 2) sekolah memiliki upaya untuk membangun, dan memelihara hubungan yang peduli, saling menghormati, mendukung, dan kolaboratif antara anggota staf sekolah, siswa, dan keluarga, 3) siswa berpartisipasi dalam pengambilan keputusan, 4) siswa menganggap aturan sebagai hal yang jelas, adil, dan tidak terlalu keras, 5) sekolah aman bagi siswa, keluarga, dan guru, 6) tersedia layanan belajar, 7) sekolah memiliki tingkat akademik dan perilaku yang tinggi dan memberikan dukungan untuk pencapaian tujuan, 8) memiliki upaya untuk mengembangkan kemampuan sosial dan emosional semua siswa, 9) guru sebagai model dalam memelihara sikap, 10) memandang orang tuadan anggota masyarakat sebagai sumber daya yang berharga, dan mereka didorong untuk terlibat aktif di sekolah.

Dalam implementasinya penciptaan lingkungan sekolah yang kondusif di MBS salah satunya dilakukan melalui pembiasaan. Pembiasaanpembiasaaan yang dilakukan di MBS terkait dengan kegiatan untuk mengembangkan karakter kemandirian siswa antara lain membersihkan pakaian, membersihkan alat makan sendiri, dan mengatur cara belajar sendiri. Semua kegiatan itu ditujukan agar siswa memiliki tanggung jawab secara mandiri terhadap dirinya sendiri. Pembiasaan yang dilakukan dalam pendidikan karakter ini sesuai dengan instruksi Peraturan Menteri Pendidikan Pendidikan dan Kebudayaan Republik Indonesia Nomor 23 Tahun 2015 Tentang Penumbuhan Budi Pekerti. Di dalam peraturan tersebut dijelaskan bahwa salah satu metode pelaksanaan penumbuhan budi pekerti di tingkat SMP dilakukan dengan menumbuhkan kemandirian peserta didik melalui kegiatan pembiasaan untuk berbuat teratur dan berulang-ulang yang dimulai sejak dari masa orientasi peserta didik baru, proses kegiatan ekstrakurikuler, intra kurikuler, sampai dengan lulus.

Pendidikan karakter kemandirian melalui pembiasaan sejalan dengan temuan penelitian yang dilakukan oleh Uliana dan Setyowati (2013:165) bahwa dalam meningkatkan pendidikan karakter pada siswa melalui srategi yang berfokus pada pengembangan kultur sekolah. Kultur sekolah merupakan keyakinan, kebiasaan-kebiasaan dan nilai-nilai yang dipegang bersama oleh seluruh warga sekolah.Pembiasaan dalam penanaman karakter kemandirian tentunya berisi nilai-nilai kemandirian yang dipegang oleh seluruh warga sekolah.

Penelitian lain yang dilakukan oleh Warsito dan Samino (2014:141-148) menemukan bahwa pembiasaan merupakan salah satu hal yang dapat ditempuh dalam mengimplementasikan kurikulum pendidikan karakter. Arinya apabila nilai-nilai karakter diharapkan dapat terinternalisasi dengan baik, maka perlu dilakukan pembiasaan secara konsisten dan kontinyu di dalam kesehariannya.

Wujud implementasi pendidikan karakter kemandirian yang lainnya adalah melalui kegiatan yang terinegrasi di dalam pembelajaran. Kegiatan pembelajaran yang pada dasarnya bermuatan aktivitas siswa di kelas hendaknya memuat nilainilai karakter yang akan dikembangkan, dalam hal ini termasuk nilai karakter kemandirian. Pentingnya aktivitas kelas dalam pembelajaran yang harus memuat nilai-nilai karakter ini didasarkan pada alasan secara teoritis bahwa pendidikan karakter di sekolah hendaknya tidak cukup hanya diajarkan secara teoritis, tetapi justru lebih baik dapat tertangkap oleh siswa melalui aktivitas kelas (Wyne, 1991:139).

Pendapat yang senada disampaikan juga Nucci \& Narvaez (2008:175) bahwa dari perspektiffilosofis, pendidik moral dan karakter memiliki peran utama dalam perkembangan moral siswa 
melalui "hiden curriculum" yang dimanifestasikandalam lingkungan interpersonal sekolah dan ruang kelas. Berdasarkan penjelasan tersebut maka jelaslah bahwa dalam upaya melaksanakan pendidikan moral, maka perlu dilakukan tindakantindakan yang tidak harus eksplisit tertulis di dalam hitam di atas putih, tetapi dapat melalui kegiatan-kegiatan di dalam kelas. Kegiatan-kegiatan di dalam kelas ini dapat memungkinkan siswa untuk menangkap pesan moral yang seharusnya mereka lakukan sehari-hari.

Nilai-nilai kemandirian dapat dikembangkan juga melalui proses pembelajaran yang dilakukan guru di dalam kelas. Metode pembelajaran yang dipilih guru dapat memberikan efek positif terhadap peningkatan kemandirian siswa. Berbagai kegiatan yang dirancang guru melalui penggunaan metode pembelajaran tertentu dapat meningkatkan kemandirian siswa, seperti halnya pemberian tugas, penyelesaian masalah terkait dengan tugastugas sekolah, dan sebagainya. Hal ini sesuai dengan hasil penelitian Sa'ban (2013:442) bahwa dalam proses perkuliahan dapat menggunakan metode pembelajaran tertentu untuk meningkatkan kemandirian mahasiswa. Dalam konteks pembelajaran di MBS tentunya metode pembelajaran yang dipilih guru harus disesuaikan dengan tingkat perkembangan siswa usia sekolah menengah.

Wujud implementasi pendidikan karakter kemandirian di MBS yang berikutnya adalam melalui penuangan dalam aturan tertulis. Aturan tertulis merupakan satu hal penting yang harus ada dalam imlementasi pendidikan karakter. Adanya aturan akan membatasi sesorang untuk bertindak atau tidak, karena berdasarkan pertimbangan sesuai tidaknya dengan peraturan. Pentingnya aturan ini sesuai dengan pendapat Dreeben yang menjelaskan bahwa sekolah, melalui pengaturan struktur dan pola perilaku guru, memberikan pengalaman tertentu bagi siswa yang sebagian besar pengalaman tersebut tidak ada dalam pengaturan sosial lainnya (Benninga, 1991:3).

Pentingnya aturan/norma dalam pelaksanaan pendidikan karakter kemandirian juga dikemukakan oleh Nucci \& Narvaez (2008:122) bahwa dalam pendidikan moral perlu melibatkan dukungan otoritatif norma. Otoritatif norma dalam hal ini dimaknai bahwa adanya aturanaturan dalam pelaksanaan pendidikan karakter kemandirian tentunya berupa pedoman tentang perilaku-perilaku kemandirian yang harus dilakukan siswa. Aturan yang ada di MBS antara lain aturan menggunakan kamar mandi, aturan menata kamar tidur, aturan jam belajar, aturan beribadah, aturan kelas, dan sebagainya.

Berdasarkan analisis data di atas, maka penciptaan iklim sekolah yang kondusif dalam rangka mengimplementasikan pendidikan karakter kemandirian MBS telah sesuai dengan yang seharusnya.Meskipun demikian memang di beberapa bagian masih membutuhkan perbaikan dalam pelaksanaan implementasinya.

\section{Kendala Implementasi Pendidikan Karakter Kemandirian}

Kendala yang pertama, yaitu kurang konsistennya orang tua dalam mengikuti aturan sekolah untuk mengembangkan karakter kemandirian tentu akan menjadi kendala untuk pencapaian hasil pelaksanaan pendidikan karakter yang optimal. Hal ini disebabkan bahwa dalam pelaksanaan pendidikan karakter salah satu unsur yang diperlukan adalah adanya kerjasama dengan orang tua.

Pentingnya dukungan/keterlibatan orang tua dalam pelaksanaan pendidikan karakter dijelaskan oleh Sheldon \& Epstein (2002:4) dalam hasil penelitiannya bahwa dengan membangun hubungan yang lebih erat dan kerjasama antara sekolah, keluarga, dan masyarakat merupakan salah satu cara yang dapat dilakukan sekolah untuk meningkatkan perilaku siswa. Dalam hal ini, maka keterlibatan orang tua yang berupa pemberian dukungan sikap konsistensi terhadap aturan sekolah dalam pelaksanaan pendidikan karaketr kemandirian di MBS perlu dilakukan agar hasil yang dicapai sesuai dengan yang diharapkan.

Kendala kedua yang dihadapi yaitu terkait dengan pengintegrasian pendidikan karakter kemandirian ke dalam proses pembelajaran. Beberapa guru mata pelajaran menuturkan bahwa merasa kesulitan untuk mengkaitkan materi mata pelajaran dengan pengembangan kemandirian santri.Kendala ini tentunya memerlukan tindak lanjut agar antara pengelola asrama dengan guru (dalam hal ini pelaku pembelajaran) dapat secara konsisten untuk selalu mengimplementasikan pendidikan karakter kemandirian. Konsistensi dalam pendidikan karakter merupakan hal penting yang harus dilakukan krena jika tidak ada konsistensi, maka akan menimbulkan kebingungan pada peserta didik dalam memaknai konsep karakter dan berakibat pada kebingungan harus berperilaku seperti apa. 


\section{SIMPULAN}

Berdasarkan hasil penelitian, maka dapat disimpulkan bahwa dalam implementasi pendidikan karakter kemandirian melalui penciptaan iklim sekolah yang kondusif di MBS dilakukan melalui kegiatan pembiasaan, terintegrasi dalam pembelajaran, dan dituangkan dalam aturan tertulis. Ketiga kegiatan tersebut dilakukan oleh MBS dalam rangka mencapai hasil implementasi pendidikan karakter kemandirian secara optimal seperti yang diharapkan.

Dalam pelaksanaan inmplementasi pendidikan kemandirian di MBS ada dua masalah yan dihadapi yaitu sulitnya menjalin kerjasama dengan orang tua untuk menjaga konsistensi. Adapun kendala yang kedua yaitu beberapa guru masih belum dapat secara maksimal mengintegrasikan pendidikan karakter kemandirian dalam pembelajaran.

\section{DAFTAR PUSTAKA}

Aini, Pratista Nor. dan Taman, Abdullah. 2012. "Pengaruh Kemandirian Belajar dan Lingkungan Belajar Siswa terhadap Prestasi Belajar Akuntansi Siswa Kelas XI IPS SMA Negeri 1 Sewon Bantul Tahun Ajaran 2010/2011." Jurnal Pendidikan Akuntansi Indonesia, Vol. X (1), hlm.48 - 65.

Beninga, J. S., 1991. "Moral and Character Education in the Elementary School: in Introduction." Benninga, J.S. (Penyunting). Moral, character, and civic education in the ele-mentary school. New York: Teachers College, Columbia University.

Berry, R. S., 1994. 100 Ideas that Work Discipline in the Classroom. Philipines: ACSI Publications.

Budimansyah, D. \& Sapriya. 2012. "Refleksi Implementasi Project Citizen dalam Pembelajaran Pendidikan Kewarganegaraan di Indonesia." Dalam Budimansyah, D. (Penyunting). Dimensi-dimensi praktik pendidikan karakter. Bandung: Widya Aksara Pers.

Dupper, D. R. 2010. A New Model of School Discipline Engaging Students and Preventing Behavior Problems. Oxford University Press, New York
Fajaria, Depriana, dkk. 2013. "Kemandirian Perilaku Peserta Didik dalam Pemilihan Jurusan dan Implikasinya terhadap Pelayanan Bimbingan dan Konseling." Jurnal Ilmiah Konseling. No 2 (2), hlm.1-5.

Glanzer, P. L, \& Milson, A. J. 2006. Legislating the Good : a Survey and Evaluation of Character Education Laws in the United States. Educational Policy, 20 (3), hlm.525-550.

Lickona, T. 1994. Educating for Character. New York:Bantam Books.

Nucci, L. P., \& Narvaez, D. 2008. Handbook of Moral and Character Education. New York: Routledge.

Sa'ban, Muhammad Nur. 2013. "Peningkatan Sikap Tanggung Jawab dan Kemandirian Belajar Mahasiswa melalui Metode Tutorial di Jurusan Pendidikan Geografi."Cakrawala Pendidikan, November 2013, Th. XXXII, No. 3.

Sheldon, S. B \& Epstein, J. L. 2002. "Improving Student Behavior and School Discipline With Family and Community Involvement." Education And Urban Society, 35 (1), hlm. 4-26.

Suparno, P. 2012. "Harapan untuk Kurikulum Baru.” Kompas, 29 September 2012.

Uliana, Pipiet dan Setyowati, Naniek. 2013. "Implementasi Pendidikan Karakter Melalui Kultur Sekolah pada Siswa Kelas XI di SMA Negeri 1 Gedangan Sidoarjo." Kajian Moral dan Kewarganegaraan No 1 (1), hlm 165-179.

Warsito dan Samino. 2014. "Implementasi Kurikulum dalam Pembentukan Karakter Siswa Kelas III SD Ta'mirul Islam Surakarta." Profesi Pendidikan Dasar, Vol.1 (2), hlm. 141-148.

Watson, M. 2008. Developmental Discipline and Moral Education. Dalam Nucci, LP., \& Narvaez, D. (Penyunting). Handbook of moral and character. New York: Routledge. 
Wynne, E. A. 1991. "Character and Academics in The Elementary School." Dalam Benninga J.S. (Penyunting). Moral, character, and civic education in the elementary school. New York: Teachers College, Columbia University. 